International Journal of Linguistics, Literature and Translation

ISSN: 2617-0299 (Online); ISSN: 2708-0099 (Print)

DOI: $10.32996 / \mathrm{ijlt}$

Journal Homepage: www.al-kindipublisher.com/index.php/ijllt

\title{
Linguistic Features of Kakawing Speeches: A Critical Discourse Analysis
}

\author{
Alyanah Goling Pantao 8(D) $\square$ \\ Associate Professor V, English Department, College of Social Sciences and Humanities, Mindanao State University, Marawi City, \\ Mindanao Philippines \\ $\square$ Corresponding Author: Alyanah Goling Pantao, E-mail: alyanahgoling@gmail.com
}

\begin{tabular}{|c|c|}
\hline ARTICLE INFORMATION & ABSTRACT \\
\hline $\begin{array}{l}\text { Received: February 08, } 2021 \\
\text { Accepted: March 20, } 2021 \\
\text { Volume: } 4 \\
\text { Issue: } 3 \\
\text { Dol: } 10.32996 / \text { ijllt.2021.4.3.26 }\end{array}$ & $\begin{array}{l}\text { This study took a serious and more probing look at one of the most interesting and } \\
\text { well-developed art forms - i.e. Meranaw orature, rhetoric, or public speaking, } \\
\text { specifically ceremonial speeches delivered at formal occasions during weddings. The } \\
\text { study is qualitative and ethnographicas as it involved participant-observation. Using } \\
\text { Critical Discourse Analysis (CDA) as enunciated by Norman Fairclough (1995) and } \\
\text { Textual Analysis of Teun Van Dijk (1998), this study aimed to identify the linguistic }\end{array}$ \\
\hline $\begin{array}{l}\text { Critical Discourse Analysis, Katharo } \\
\text { sa lalag, Bangsa }\end{array}$ & $\begin{array}{l}\text { features of the ceremonial speeches and discover the values reflected that shaped the } \\
\text { ideology of the Meranaws. The values dicoveres were classified to three frameworks- } \\
\text { social, political and religious. The findings revealed that Meranaw speech is rich with } \\
\text { islamic lexicons that praises Allah, compliments and honorifics, lietmotifs, local words, } \\
\text { idiomatics expression and figures of speech which describes the nature of marriage } \\
\text { and its relevance in Meranaw society. The study revealed that the values identified } \\
\text { defined and shaped what is essential among the Meranaws-the concept of Bangsa } \\
\text { (clan). Marriage among the Meranaws is not just a union between the bride and } \\
\text { groom but the union of the clans to maintan the status que of the family and preserve } \\
\text { purity of the blood line. Marriage is used to impower and elevate the status of the } \\
\text { family through kathothonganaya (close family ties), kapagisa-isa (unity) and } \\
\text { kambatabata (tightening relationship). }\end{array}$ \\
\hline
\end{tabular}

\section{Introduction}

The Meranaws are known as the people of the lake. They settled around the edge of Lake Lanao, located at the Islamic City of Marawi, Philippines. The lake is surrounded with myths and legends. Renowned Meranaw Poet Datu Tingcap G. Pandi said that the word "Meranaw" is a compound word composed of "mera" which means "peacock" and "naw" which means "awake". In other words, "meranaw" means "an awake peacock". The Meranaws are the largest Moro and cultural minority in the Philippines. Generally, Meranaws are Muslims. In the Philippines, they are regarded as the most traditional Muslims resistant to changes and defensive of their culture (cited in Madale and Cheng 1994). As Muslims, they are adherents of Islam, a religion founded and established by Mohammad. The Meranaw's unwavering sense of cultural identity is based largely on the Meranaws Islamic faith and a centuries-old history of resistance to Spanish, American, and Manila-based attempts to take control of their homeland (Riwarung, 2009).

Recently, it has been a common observation that most Meranaws, especially the present generation, have less appreciation of the rich characteristics, beauty and unique features of their language especially during formal ceremonies such as wedding ceremonies. They also do not even bother to practice the art of katharo sa lalag (delivering a speech) a unique and special skill among the Meranaws because they do not understand its meaning and relevance as part of their identity. Thus, studying this at present is very timely. Furthermore, no studies have been made about Meranaw wedding speeches gathered from the field as corpus This study offers a fresh contribution to the body of knowledge about the language of the Meranaw which remained mysterious to outsiders. It aims to shed more light on the Meranaw values and beliefs embedded in the speeches of the maungangen (orators).

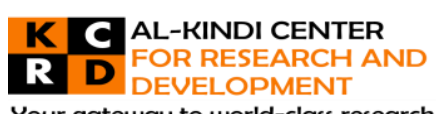

Your gateway to world-class research

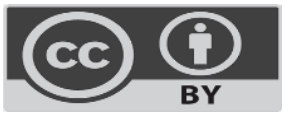

Published by Al-Kindi Center for Research and Development, United Kingdom. Copyright (c) the author(s). This open access article is distributed under a Creative Commons Attribution (CC-BY) 4.0 license 
Katharo sa lalag (delivering a speech) is a public recital by the pananalsila (tracer of lineage) of the lineages of both the bride's and the groom's families. One reason for the katharo sa lalag (delivering a speech) is to make public the "noble" lineages of both families and affirm that both are of the same class. It can also be recited to praise and extol both families. The speakers used sophisticated language and old Meranaw words that others do not understand its meaning. The language used reflect different values that shape their identity and ideology. Ideologies consist of social representations that define the social identity of a group, that is, its shared beliefs about its fundamental conditions and ways of existence and reproduction (van Dijk, 2006).

The central problem this paper addresses, or concerned with, is to demonstrate how the linguistic properties of the speeches are linked to sociocultural, religious and political values leading to their identity and to bridge the existing gap of inquiry in this direction. It investigates the linguistic features of the Kakawing (wedding) speeches, the discourses and meaning embedded in the texts. The researcher sough to analyze its meaning and discover the values of the Meranaws manifested in the identified linguistic features using Critical Discourse Analysis as the framework of analysis.

\section{Methodology}

The study uses Critical Discourse Analysis specifically Norman Fairclough's (1995) textual analysis and Teun van Dijk's (2011) Social Cognition Discourse, when viewed as style; a system of address, and verbal art or stories occurs within a sociocultural and historical context, with its variants (Halliday 2006). The study aims at evaluating the linguistic properties and components, core in the texts of the Kakawing (wedding) speeches, to assess their import in understanding the the Meranaw.

To gather texts to comprise the corpus for analysis, the researcher went to the field. By field she means Meranaw weddings. She attended a number of weddings and recorded the "keynote speeches" who delivered at these events. The researcher selected fifteen out of twenty speeches delivered by fifteen different speakers that comprised the corpus of texts to be subjected to CDA. The collected speeches were recorded/videotaped in situ, transcribed, and translated to English preparatory to analysis. As most of the speeches were liberally studded with classical Meranaw - e.g. pananaroon or proverbial sayings, cryptic analogies and allusions, and metaphorical language - a native speaker of Meranaw who is familiar with Meranaw rhetoric was consulted on the translations made by this author to ensure accuracy of faithfulness to the original texts in Meranaw.

\section{Results and Discussions}

The following discussion presents the analyses of the linguistic features of the Meranaw speeches delivered at weddings.

\subsection{Linguistic Features of the Speech}

The Meranaw Speech has a distinctive characteristics of features unit that distinguish from other speeches. The researcher was able to identify the different rhetorical moves of katharo sa lalag (speech) during kakawing (wedding) of the Meranaws. They are the Pamekasan (introducton), moayan a lalag (message of the speech) and kaposan o lalag (conclusion or ending of the speech). The researcher identified the different linguistic features of the mentioned rhetorical moves, making the Meranaw speech unique from other speeches delivered during wedding in other cultures.

\section{Linguistic Features of Pamekasan (Introduction)}

The Pamekasan (introduction) of Meranaw speech in kakawing (wedding) is very unique and different from other speeches. It is very notable that the introduction is the longest part of the speech. Aside from its length, it has unique features which include the greeting of salaam, praises to Allah, abundant use of honorifics and compliments.

\section{Greetings of Salaam}

The speech customarily opens with salutation or greetings in Arabic. The conventional Islamic greetings -- "salaam" and praises of Allah(s.w.t.), as Almighty God is referred to, or addressed by the faithful adherents of Islam, and of his messenger, the prophet Mohammed (s.a.w.) or the last "Rasul" (messenger or prophet).

However, the lexical items used in praising Allah and the prophet Mohammed, varies in terms of length and elaboration, from the one liner "Assalamo alaikom" and the two-sentence "Bismillahi rahman ni raheem. Assalamo alaikom warahmatullahi wa barakato" to longer versions of the Islamic greetings such as the first on the list provided below Despite the great variety, one notes consistency in the use of "salaam" and the line invoking Allah.

The use of salaam is one noticeable unique feature of the pamekasan (introduction): it seems to eschew or avoid using the most common western form of greeting of "good morning" or "good afternoon". Although the Philippines was once colonized by the Americans, Muslim Filipinos or the Bangsamoro (this includes thirteen Muslim groups in Mindanao) take pride in their having never been subjugated or conquered by the former. Avoiding English greetings can be surmised as a way of denying or rejecting American influence; it hints at a kind of resistance. 
Opening one's speech with the traditional conventional Islamic greetings immediately distinguishes or identifies the speaker how language is bound up with the speaker's identity. This also helps the speakers to identify themselves with the audience. Burke (1950) called this identification in new rhetoric which is a form of persuasive appeal. Identification is how the speaker associates himself/herself with certain group, such as the target audience (Burke, 1950). By greeting the audience with Islamic greetings, the speakers were able to associate themselves to the audience identity as a Muslim.

Salaam is more than a greeting, for it also signifies including Allah in the important affair - the wedding or solemnization of the union and beginning of life together of the couple. This is shown by using series of superlatives used for God - for example, "most gracious" and "most merciful" -- make a set piece, thus formulaic. There is no room for variation here. The Deity is described in this traditional manner. According to Searle's categorization of speech act, greetings fall into the category or expressive speech acts. The speech act of greeting is particularly appropriate through which we can find out what is valued in a particular culture (Searle, 1969). Thus, the use of salaam and inclusion of Allah and Mohammed signifies that the Meranaws value their religion to include it in their speech.

\section{Praises to Allah}

All Meranaw speeches contain praises to Allah (s.a.w) and the prophet Mohammed (s.w.t.) and this is very redundant in pamekasan (introduction) of the speech. Since Meranaws are adherents of Islam, this is not surprising. Below are the words used for exalting Allah; these are mostly descriptions of Allah's limitless goodness, beneficence, compassion and power.

Table 1: Lexical Items that Praises Allah

\begin{tabular}{|c|c|}
\hline MERANAW & ENGLISH \\
\hline Da a pawing lyan & Perfect \\
\hline Da lagid lyan a masalinggagaw & Exceptionally or incomparably merciful \\
\hline Makarorokom a langowan a bantugan & Praised by all creatures for His perfection \\
\hline A kapopoonan o limo & Source of blessings/mercy/compassion \\
\hline A makapkikineg ko kadaledaleman o poonan a pakalinggagaw & The source of all blessings \\
\hline $\begin{array}{l}\text { Makatatangan ko kapaar ago so kambayambaya sa } \\
\text { kaangkosi niyan ka sangkai a dalem a donya }\end{array}$ & $\begin{array}{c}\text { Who is supreme and has every power and control of this } \\
\text { universe }\end{array}$ \\
\hline Rahim & Most beneficent \\
\hline Rahman & Most merciful \\
\hline Sindaw a maliwang & Rays of the radiant light \\
\hline
\end{tabular}

All the descriptions of Allah are expressed through superlatives. The message is, the Supreme Being is not commensurable, non pareil, ne plus ultra, or peerless. Speakers do not forget to mention the name of Allah and extol His perfection and power throughout the speech.

Kagya so Allah, matatangked a makarorokom a langowan a bantugan, na sekanyan i makanggagangam ko langon a podi, a kapopoonan o limo a makapkikineg ko kadaledaleman o aden a poonan a pakalinggagaw a makalalayam o kadaledaleman o sai. Sekanyan i makatatangan ko kapaar ago so kambayambaya sa kaangkosi niyan ka sangkai a dalem a donya, na sampay pen ko alongan a plindodan darpa a aden a poonan iyan na da a kaposan iyan a tatapolen si langon a wal.

Because Allah controls all creatures, owns all praises, source of blessings, knows everything. He is the most righteous and controls whatever we have today, in the life hereafter, no beginning and no ending.

The excerpt manifests the influence of Islam which permeates everything, including Meranaw speech. It can be concluded that present Meranaw speech in kakawing (wedding) is an interaction or fusion of Islam and native Meranaw culture. Such combination is known as syncretism. Syncretism is a tendency or effort to reconcile and unite various systems of philosophy, or religious opinion on the basis of tenets common to all, and against a common opponent (Webster Dictionary, 1986; in RogongRasul, 2015; also, in Ayo, 2016). Jerry Bentley (1993) argued that syncretism has also helped to create cultural compromise. It provides an opportunity to bring beliefs, values, and customs from one cultural tradition into contact with and engage different cultural traditions.

\section{Honorifics}

According to Sunil Kumar Bhalt (2015), honorific in a language have a very important role in the interplay of respect, familiarity, and formality based on age, familiar relationships, level of personal acquaintance, social hierarchy, status and so forth among the members of the society. The following table shows the different honorifics used in speech. 
Table 2: Different Honorifics Used in Speech

\begin{tabular}{|c|c|}
\hline TITLES & EXAMPLES \\
\hline ROYAL TITLE ( Grar or Traditional Title) & $\begin{array}{c}\text { Sulutan, Datu, Bae, Potri, Maamor, Sulutan, Guro, Radiamoda, } \\
\text { Maruhomsidiekh, Kali, }\end{array}$ \\
\hline LOCAL & Governor, Congressman, Mayor, Vice Mayor, Vice Governor \\
\hline REGIONAL & Assemblyman, Board Member \\
\hline TITLE OF DEGREE & Doctor, Engineer, Attorney, Maestro Maestra, Teacher \\
\hline
\end{tabular}

The speech contains different names from different sectors of the society. These include not only members of the family but also guests who have traditional royal titles called grar such as Sulutan, Datu a Cabugatan, Ampuan, Bai a Labi, and Radiamoda, regional and local positions such as congressman, mayor and councilor, and personalities, such as Councilor, Municipal Treasurer, Assemblyman and Barangay Chairman, and others who have prestigious professional titles, for example, Doctors, Engineers, Attorneys and Directors.

Honorifics are politeness formulas in a particular language which may be specific affixes, words, or sentence structure (Richards et al., 1993). The speakers used honorifics to conveys esteem or respect for personages by virtue of their position or rank used in addressing or referring to a person. For the Meranaws, the use of honorifics is de rigueur; it is more than recognition and conveying esteem or respect for it is also used as a means to show how one values the person and how one honors him. Thus, the redundant mention of honorifics shows how much they honor and the persons with title. They celebrate the titles of their relatives by acknowledging them in the speech.

The Meranaws are a very proud people. They take pride in every achievement of a family member which is considered as an achievement of the whole clan. Thus, tarpaulins usually highlight more than four family names of a person who has achieved or accomplished something notable, such as educational attainment and professional success (Ibrahim, 2018). By using honorifics, Meranaws vaunt the achievements of their members of the family, or relatives.

\section{Compliments}

According to Holmes (1986), a compliment is a "speech act which explicitly or implicitly attributes credit to someone other than the speakers, usually the person addressed, for some good possession, characteristic, skill, etc which is positively valued by the speaker and the hearer. The constant use of compliments in Meranaw discourse implies that the Meranaws are polite and not merely using compliments for flattery. This is what Brown and Levinson (1987) called positive politeness strategy. The Meranaw compliments were used to notice and attend the hearer's face and seek agreement. Furthermore, they are used it is a strategy as speakers notice and attend to the speaker's wants, interests and needs. The following table are the compliments found from the data.

Table 3: Different Compliments Used in Speech

\begin{tabular}{|c|c|}
\hline MERANAW & ENGLISH \\
\hline Pagari ko a bolawan & My golden sibling \\
\hline Lokes & Old folks \\
\hline Pagari & Siblings \\
\hline Kababantogan & Famous \\
\hline Mapamaratia & Believer \\
\hline Kalilimod a mapiya & Beautiful affair \\
\hline Kapipya ginawa & Happiness \\
\hline Bilang a tao & Noble \\
\hline Malay limo & Beneficent \\
\hline Malay gagaw & Merciful \\
\hline Mapened & Heavy \\
\hline Kabinaningan & Golden \\
\hline
\end{tabular}

The table reveals the Meranaw penchant for compliments in the form of metaphor or even hyperbole, for example, pagari ko a bolawan, which the speaker uses to address the "principals" or major players in the event. They are as gold to him. Other 
members of the audience are referred as lokes which, though literally meaning old folks, actually means more than that. To be referred to as "lokes" in Meranaw society is to be recognized as someone highly respected or esteemed and venerated. The word carries pleasant connotations that include wisdom and pride in being related to such a person.

The kaseselai ko peloke-lokesen is the Meranaw version of filial piety (xiao sun). Younger Meranaws defer to the wishes, opinions, and advices of their elders. Lokes (old) and pagari (siblings) are compared to, or prized as treasures. These terms lokes and pagari carry special nuances.

The data also reveals a number of compliments such as kababantogan (famous), mapamaratia (believer), kalilimod a mapiya (beautiful affair), kapipiya ginawa (happiness), bilang a tao (noble), malay gagaw (merciful), malay limo (beneficent) and mapened (heavy). The compliments are examples of what Yuan (2002) referred to as unbound semantic formulas which refer to expressions that can function independently as compliments (Yuan, 2002).

The Meranaws value their families and relationships to others. Family is considered a treasure. This is why Meranaw families believe in prolificity or large families. Despite the looming global economic crisis, they unabashedly show preference for large families and still faithfully carry out their literal interpretation of "Go out and multiply." The more children one has, the better, for this is already considered a treasure.

Mention of the golden color of the Meranaws -- "kabinaningan" -- is very significant for the golden color is a very important symbol in the Meranaw culture. The golden color symbolizes royalty, power, and status. It is a royal color, thus immediately associated with the elite or aristocracy (Pantao, 2016). It symbolizes the Meranaw royalty. For example, the phrase "benaning $i$ olo" (of yellow head) is a metaphorical expression or epithet for the blue-blooded (Sharief, Minang). Benaning di komelas (unfading yellow) in the Darangen refers to the king or queen who is of royal stock from the very beginning and not only through marriage. Thus, the speaker's emphasis of the guest wearing golden dress is his subtle way of emphasizing the status of the guests who are royalties.

\subsection{Linguistic Features in Moayan a Lalag (Message of the Speech)}

The moayan a lalag (message of the speech) contains different messages including the nature of marriage and its importance, prayers, enumeration of family names, tracing the lineage with salsila and power of clan and relationship. In relaying these messages, different linguistic features were used. They are the following.

\section{Figures of Speech}

The moayan a lalag (message of the speech) contains figures of speech including metaphor, image, simile, allusion and parallelism. Figures of speech often provide emphasis, freshness of expression, or clarity. The following table lists the figures of speech found in moayan a lalag (message of the speech).

Table 4: Figures of Speech Used in Moayan a Lalag (Message of the Speech)

\begin{tabular}{|c|c|c|}
\hline $\begin{array}{c}\text { Makaselang sa maliwag a angkai a } \\
\text { dowakatao }\end{array}$ & Metaphor & For these two to see the lights \\
\hline Maluya matimos & Metaphor & Spicy and salty \\
\hline $\begin{array}{c}\text { Inipangilay sa kamapyaan } \\
\text { kyakarongaw so andang a } \\
\text { kangiginaway o mga lokes }\end{array}$ & Metaphor & Searching for good \\
\hline $\begin{array}{c}\text { Na maksisibarat sa bolawan limpiyo na } \\
\text { matatangked so linang }\end{array}$ & Simile & $\begin{array}{c}\text { Opening the window of the old } \\
\text { friendship of our ancestors }\end{array}$ \\
\hline $\begin{array}{c}\text { Myakarongaw so andang a } \\
\text { kangiginaway o mga lokes } \\
\text { the purity or genuineness of this } \\
\text { bangsa is precised }\end{array}$ \\
\hline $\begin{array}{c}\text { So andang a kangiginaway o mga lokes } \\
\text { na iniped iran a gyuto a mga wata iran } \\
\text { na ba siran baden mimbala }\end{array}$ & Allusion & $\begin{array}{c}\text { Opening the window of the old } \\
\text { friendship of our ancestors }\end{array}$ \\
\hline $\begin{array}{c}\text { Sabap sa iisa tano. Langon tano mga } \\
\text { meranaw, langon tano mga moro, } \\
\text { langon tano mga muslim. }\end{array}$ & Parallelism & $\begin{array}{c}\text { Forged and cherished by their } \\
\text { ancestors }\end{array}$ \\
\hline $\begin{array}{c}\text { Because we are one. We are all } \\
\text { Meranaw. We are all Moro. We are } \\
\text { all Muslims }\end{array}$ \\
\hline
\end{tabular}




\begin{tabular}{|c|c|c|}
\hline $\begin{array}{c}\text { Tinimbang so perak ago bolawan na } \\
\text { mapened so bolawan. Na tinimbang so } \\
\text { bolawan ago montiya na mapened so } \\
\text { montiya. Na tinimbang so montiya ago } \\
\text { bangsa na mapened so bangsa na } \\
\text { mapapadelem saya sa kangiginaway, } \\
\text { na kaseselaye na maana na gyoto so } \\
\text { kambatabataa. }\end{array}$ & Proverb & $\begin{array}{c}\text { Money and gold were weighed, } \\
\text { gold was heavier. Gold and } \\
\text { diamond were weighed and } \\
\text { diamond was heavier. Diamonds } \\
\text { and clans' relationships were } \\
\text { weighed and clans' relationships } \\
\text { proved heavier and this includes } \\
\text { friendship, honoring, and } \\
\text { relationship }\end{array}$ \\
\hline
\end{tabular}

The moayan a lalag (message of the speech) is very rich in figures of speech including metaphors, images, allusion, simile antithesis and parallelism and powerful pananaroon (proverbs).

Makaselang sa liwanag (literally, to see the light) is a metaphor expression that wishes upon the couple finding their way to a bright or well-lighted future together. The expression has the solemnity of a prayer. The speaker hopes that the marriage will bear only good or profit not only for the newlyweds but also for their families.

The metaphor maluya matimos (literally spicy and salty) is used by the speaker to refer to the groom's family and the reason for the inevitability of welcoming them as relations. It is roughly synonymous to the English "through thick and thin". The use of "maluya matimos" underscores the gravity of that family's help. This means they can be counted or relied on under any circumstance. Meranaws highly value this particular trait: kesarigan (one you can trust) or kasanaan (one you can hold). People who have this will stand by and with you, through the worst straits.

Inipangilay sa Kamapyaan (Searching for good) is a metaphor frequently and repeatedly heard in connection with marriage. Literally it means "search" or "quest" for what is good. Thus marriage, is a search for something beneficial, gainful, or profitable. There is no more concrete proof of this than the all-out support the family referred to in the passage provided when the speaker's son ran for office in the city.

The bangsa (clan) of the bride was compared to a simile "bolawan limpiyo na matatangked so linang" (gold of the purest kind, and the purity or genuineness is precised). This simile describes how precious their bangsa (clan) is by comparing it to a gold which is genuine and precise.

The image myakarongaw so andang a kangiginaway o mga lokes (opening the window of the old friendship of our ancestors) and the allusion so andang a kangiginaway o mga lokes na iniped iran a gyuto a mga wata iran na ba siran baden mimbala (Forged and cherished by their ancestors refers to the old friendship of their old folks. The "opening of window" (miyakarongaw) is a vivid image for the renewal of friendship or ties. It expresses a nostalgia or yearning for the days of the ancestors when their ties were closer and more binding. Over time, the old ties loosen and members of the same descent or clan or friends tend to drift farther and farther away from one another as new relationships are formed.

The parallelism is what De Beaugrande (1984) describes as repetition of a structure. It is the "reusing surface formats but fulfilling them with different expressions". The example expresses similar thoughts, not identical noun, are expressed in parallel sentence. Using different lexicon, the speaker effectively emphasizes his message-that the Meranaws are one. The use of the pronoun "tano" (we) and of passive voice also gives an effect to the message. As mentioned by Weaver (1967), the passive voice gives emphasis to parts of the sentence which normal word order does not emphasize by moving the grammatical object to the position of subject.

\section{Pananaroon (Proverbs)}

Meider (1985) has defined proverbs as short, generally known sentence of the folk which contains wisdom, truth, morals, and traditional views in a metaphorical, fixed and memorizable form and which is handed down from generation to generation. The following is one of the many examples of Pananaroon (Proverbs) used in Moayan a Lalag (message of the speech):

Tinimbang so perak ago bolawan na mapened so bolawan. Na tinimbang so bolawan ago montiya na mapened so montiya. Na tinimbang so montiya ago bangsa na mapened so bangsa na mapapadelem saya sa kangiginaway, na kaseselaye na maana na gyoto so kambatabataa.

Money and gold were weighed, gold was heavier. Gold and diamond were weighed and diamond was heavier. Diamonds and clans' relationships were weighed and clans' relationships proved heavier and this includes friendship, honoring, and relationship. 
This (proverb) used analogy to make clear what is most precious to the Meranaws: relationships or ties, friendship, mutual regard and honoring. It outweighs everything considered valuable in the world: money, gold, and diamond. Thus, the strengthening of ties is the greatest gain from the union of two families/clans through marriage.

\section{Emphasis}

The speech contains different words repeated repeatedly to emphasize a main point and create a powerful cohesive effect. By repeating this word/ phrase, you can leave a powerful impact.

Table 5: Repeated Words/ Phrases in Moayan a Lalag (Message of the Speech)

\begin{tabular}{|c|c|}
\hline MERANAW & ENGLISH \\
\hline Lokes tano & My old folks \\
\hline Wata tano & Our children \\
\hline Pagari tano & Our siblings \\
\hline Babay tano & Our sisters \\
\hline So mga panorogan, & The nobles \\
\hline So mga sulutan, & Sultans \\
\hline So di nggoberno & Government \\
\hline Ko kapakaolad o ompia sa ranao & Spread of Progress in Lanao \\
\hline Balabalasan kano o allah & May Allah blessed you. \\
\hline Bapya baken sekano den marangkom & May I simply acknowledge you as a group? \\
\hline So tlo maruhom so kitetendu iyan. . & The three maruhom \\
\hline
\end{tabular}

The most commonly used device of emphasis is repetition not only of key words, but also of patterns. Examples of repeated key words and patterns are are lokes tano (my old folks), wata tano (our children), pagari tano (our siblings), and babay tano (our sisters).

\section{Leitmotif}

According to C. Hugh Holman, leitmotif is "...an intentional and recurrent repetition of a word, phrase, a situation or an idea, 181 [which] tends to unify a work" (par. 19). The term was coined by F.W. Jahns in 1871 to refer to a closely defined theme or musical idea, representing or symbolizing a person, object, or idea which returns in its original or an altered form at appropriate points in a work. (The Grove Concise Dictionary of Music par. 12).

Ineluctably, because of the focus on certain themes, signifiers of these themes recur or are strewn all over every text. These signifiers or terms are called leitmotifs. 'Leitmotif', a term borrowed from music, is a recurrent word of phrase, clause or sentence carrying a meaning that is important to the subject. The simple repetition of this key word or expression binds together the parts of a text or its portion. In other words, it is an effective unifying device. The next table identifies the leitmotifs that were used by the speakers.

Table 6: Table of Leitmotifs

\begin{tabular}{|c|c|}
\hline MERANAW & ENGLISH \\
\hline Bangsa & Clan \\
\hline Taritib o inged a Ranao, & Custom of Lanao \\
\hline Pat a pengampong a ranao & Four sovereign states \\
\hline Mga lokes & My old folks \\
\hline Pagari ko, & My siblings \\
\hline Mindiamonga, & Marriage \\
\hline Kakapayag o lalag, & Delivering the speech \\
\hline Kanggiginawayi & Friendship \\
\hline Kaisaisa o mga lokes tano & Unity \\
\hline Bulawan & Gold \\
\hline Benaning/kabinaningan, & Yellow/yellowish \\
\hline Kiyaisa-isa/kapagisa-isa, & Unity \\
\hline
\end{tabular}


These recurrent words point up the key ideas in the discourse. Added up, they form a picture of what is essential, vital, significant and meaningful in Meranaw culture. Another class of unifying device consists of signposts which aid in pointing out the structure of the text. These pointers include any word or phrase, or even sentence, or any extraneous device that tells the reader what the speaker has just done, or is to do next, or intend to do later.

\subsection{Linguistic Features of Kaposan a Lalag (Ending of the Speech) Maaf (Apology)}

One important content of the speech is the repetitive asking of maaf (apology, pardon) by the speakers. This apology is not to ask forgiveness for any error actually committed by the speaker but for the error or lapse he may have committed or might commit that he is not aware of. The speaker is aware of his humanity. No matter how competent and gifted he is, he is as vulnerable as any mortal. No matter how meticulous he tries to be, he is not above making lapses or mistakes. So, as a pangali or sanggila (precautionary move), before a slip happens, he advances his profuse apologies for this. This show of humility has a mitigating or extenuating effect on whatever mistakes may be committed.

Maaf is an Arabic word which means "sorry" or "pardon". In Islam, asking apology and accepting apology are a virtue. The Prophet Muhammad (s.w.t.) has said, "O' 'Ali! My intercession shall not reach the person who does not accept the apology from another person -- whether the apology is truthful or untruthful" (Ethical Discourses).

Goffman (1971) views apologies as remedial interchanges serving to re-establish social harmony after a real or virtual offense, or in Olshtain and Cohen, terms whether the offense is real or potential (1983, p. 20). Apology is a communicative act in the production of which the person has to act politely, both in the vernacular sense and in the more technical sense of paying attention to the addressee's face wants (Brown and Levinson, 1978, 1987).

Even more in Meranaw society, apologies are associated with face-saving, face-giving, or loss of face. Contrary to study of Kampf Zohar (Public (non-) apologies: The Discourse of Minimizing Responsibility, 2009) who claimed that apologies can undermine the public figure's desired face, and project an image of a person who is lack of capabilities, asking for apology in Meranaw culture is seen as positive for it indicates sensitivity to the Meranaw's maratabat (pride).

The face is a metaphor for public self-image. Goffman (1967) conception of face focuses on the idea that face is a positive a social value that a person effectively claims for himself. The importance of face for a Meranaw is made explicit in the idiomatic expression or proverbial saying "satiman i paras" (literally, one-faced or having only one face) which every individual who values his worth, honor and dignity, and who has self-respect, says of himself. Loss of this one face means loss of everything. Thus in Meranaw society, facework is paid serious attention. This involves the enactment of specific verbal and non-verbal messages that help maintain and restore face loss, and uphold and honor face gain.

Apologies or appeals for forgiveness, understanding, and indulgence are among such verbal messages. This supports Goffman's (1967) idea that such face-loss can be sought to be repaired through a corrective facework-of which the apology is a major part of the interchanges designed to repair this potential damage to face.

In Meranaw culture, asking forgiveness and accepting the apology of a person who humbles himself by offering his apologies are both ethical and Islamic values.

In katharo sa lalag (delivering a speech) during a wedding, the speaker apologizes not because he has committed error. This is known as "pangali" in Meranaw culture meaning better to be safe than be sorry later. Even if he has not committed any mistake during his speech, he wants to make sure that if there is something wrong, he has committed in the eyes of others or if he has offended anyone without his knowledge, the speaker is sorry. This is amanifestation of sensitivity to the Meranaw maratabat (amor propio, pride). This is very important especially because a Meranaw wedding is witnessed by hundreds of guests and graced by important people in society. Below are examples of how speakers ask for maaf (apology).

Na pamangni ako rekanopen sa maaf oba aden a dako katarotopi ko kiyapayag o sariat o lalag ko sabap sa kangodaan akopen a gopen gii sinanad, sa ayamala na sobo so kadnan I daa pawing iyan.

I'm asking for an apology if I have not completed the speech for, I am still young and only God does not commit mistake.

In the example above, the speaker uses his youth as an excuse of justification for what he believes is an inadequacy - i.e. his speech failing to measure up to the audience's expectations. For a clincher, he rests his case with a variation of the oft-quoted proverbial saying that only God is perfect or infallible. Thus, he appeals for the audience's understanding and empathy for whatever in his speech has displeased them or they found wanting. The phrase "so kadnan I daa pawing lyan" (only God commits no mistake) is an effective rhetorical device of justifying or defending oneself since no one would dare object to the fact that only God commits no error. 
A wedding ceremony is a very formal and big affair and committing an error is a serious matter. By saying that God is the only one who does not commit mistakes, it means that people should be more tolerant and forgiving of the faults or mistakes of others. To reiterate, this disclaimer is a very effective rhetorical device in clinching an argument. There is nothing more appealing or winning than humility as opposed to arrogance or hubris. In Meranaw culture, pangembabaan (being humble) is admired as a virtue especially when exemplified or modeled by someone reputed for his talent or expertise.

\subsection{Values Manifested by the Linguistic Features of the Speech}

Different values of the Meranaws were embedded in the identified linguistic features of katharo sa lalag (delivering a speech). They are being religious, social stratification, kathothonganaya (close family ties), kapagisa-isa (unity), kapamakala (increasing) and kambatabata (tightening relationship).

\section{Religious}

As shown from greetings of salaam and constant praises to Allah, the Meranaws are adherent of the religion Islam. They are religious and practicing Muslim.

The salaam salutation is the speaker's way of announcing that he is a Muslim speaking to fellow Muslims. It is a potent means of immediately establishing rapport with the audience. It is more than a greeting for it also signifies including Allah in the important affair - the wedding or solemnization of the union and beginning of life together of the couple. The use of salaam signifies the integration of Islam in Meranaws' life, especially in one of the important life events, the wedding. Their being religious is also manifested with the constants mention of praises using different modifiers such as most merciful, most beneficent and perfect.

\section{Social Stratification}

The Meranaws value the status of the members of their family. The constant use of honorifics such as royal titles, political titles and professional titles when delivering a speech show how Meranaws value the status quo of the aristocrats and upper class. They celebrate this status by announcing the titles of the guests repeatedly. They boast their status and position in the society. . Royal families are recognized, respected and given importance. As what Velsaco said, "the Maranaos have a higher respect for those who belong to the upper stratum of the society than those who belong to the lower class."

The importance of status is also shown when the speaker gives different compliments to the guests who are present such as kababantogan (famous), mapamaratia (believer), kalilimod a mapiya (beautiful affair), kapipiya ginawa (happiness), bilang a tao (noble), malay gagaw (merciful), malay limo (beneficent) and mapened (heavy). This is to paint a good image of the guests who are present in the wedding.

The importance of status quo is also emphasized in the "moayan a lalag" (message of the speech) when the speakers mention the family names of the bride and groom and their origin to trace the lineage of the families. As mentioned earlier, the purpose of the salsila is not only to trace the connections of the couple with the ultimate goal that they belong to the same clan but also to identify the social structure of the couple whether they belong to mapiya a tao (pure) or kasilidan (mixed blood). The Meranaw society is divided into two strata; Namely, Mapiyatao (Pure) and Kasilidan (Mixed blood). Kasilidan is further subdivided into categories which are as follows; sarowang (non-Maranao), balbal (Beast), dagamot (Sorcerer/Sorceress) and bisaya (Slave). The mapiyatao are those natives who are entitled to ascend to thrones claim a traditional title royal bloodline. On the other hand, the kasilidan are those natives whose bloodline is dubious or suspected as mixed and even polluted or contaminated.

\section{Kathothonganaya (Close Family Ties)}

Based on the structure of the text, Moayan a lalag emphasized the importance of kathothonganaya (close family ties). Different linguistic expressions were also used to emphasized its gravity such as "oba miyakarongaw so andang a kanggiginaway o mga lokes" (to open the window of the old friendship and "sabap sa maphakarani niyan so miyakawatan a kathotonganaya (so that the distant kinship will be close).

The Meranaws are known or being clannish. The Maranaos are clannish. Whenever family feuds happen, and achievements and successes are earned, they take sides and are very supportive (Saber and Madale, 1975). Kathotonganaya (close family ties) is very important in Meranaw society. It is a value that must be observed in order to maintain the strength of the bangsa (lineage). The primary social welfare or support system for the Meranaw is the family. In the Meranaw society, this means extended family or clan, or all the "kith and caboodle". When the families are close to one another and maintain a good relationship with the members, the more they become stronger as a clan.

Lastly, the importance of kathothonganaya (close family ties) is shown at the last part of the speeches where the speakers by saying "thank you" and asking for maaf (apology). Asking form maam(apology) is a form of pangali (precaution) for even if the speaker has not committed any mistake, he still asks for apology. As mentioned, wedding is a serious and formal affair, and 
offending any audience member is a serious matter. Thus, to maintain a good relationship with the audience, speakers apologize.

\section{Kapagisa-isa (Unity)}

Kapagisa-isa (unity) is a prized Meranaw value that reflects the "we- feeling of perspective" characteristic of a collectivistic culture as opposed to the individualistic culture. Traceable to the age of the ancestors of the Meranaws and reinforced by Islam with its declared goal of unity and universal brotherhood as its most importantsocial goal, unity underlies family or kinship cohesiveness. Speakers used the simile "Kapal na melagi-lagid a umpong iyan" (Ships that have the same destination) to describe how they are united united in the following excerpts.

Opama o ki-ibarat ta sa kapal na melagi-lagid a umpong iyan kagiya magari-ari so mga datu na magari-ari so mga bae na miya bambar na giya tnge-tnged minsan a mga bangsamoro a meranao.

If you compare it to a fleet of ships, they have the same direction for men are siblings and the women are siblings and they procreate and became cousins of the nation of Meranaws or Bangsamoro.

Like the ships that have the same direction, the Meranaws are united as one. Furthermore, another speaker emphasized this concept in the following excerpt.

Sabap roo na giyangkai a kapakatalingoma ami na giyaden I kiyaisaisa rekami a gya a pagari aken a kapapantagan a City Comission Officer sii sa City a Marawi a aya myatalingoma.

Because of that, our presence shows how we are united. We are united with my brother who is the current City Commission Officer of Marawi city whose affair is this.

The communal spirit reigns in a Muslim community. This spirit asserts itself and comes to the fore when a member of the family or clan, including-in laws (by consanguinity or affinity), need to be uplifted in times of need or distress. The communal feeling of kapagisa-isa is translated to resource-giving or accessing. Any material or non-material assistance is extended and received; this "help" is known as tabang (help) in Meranaw. Uplifting the life of their relative and others in the community, or helping out in times of crisis is a social obligation in Islam. In Islam, one's relationship to others is compared to the human body. Pain felt at one's extremities radiates throughout the whole body.

\section{Kapamakala (Increasing)}

Kapamakala (Increasing) in Meranaw society has to do with pride or maratabat. It denotes elevating or raising up kinsmen. This is clearly manifested with honorifics in pamekasan (introduction) and tracing the lineage through salsila.Narrating the salsila of the two parties which is one of the recurrent themes in the speeches is a way of showing that they belong to pure lineage. In most of the texts, the speakers elevate the status by mentioning their titles and achievements and mentioning the connections of the concerned families to most prominent or blue-blooded families - the local aristocracy or nobility. This is what the following passage means:

Na aya mataan na benar den ka opama o pagilayen o bangsa a giya pyangilayan iyo sa kamapiyaan na makasisibarat sa bolawan I irang a limpiyo na matatangked so linang bangsa niyan sa pengampong a Ranaw.

The truth is if you will look at the clan of this people, it is like gold that pure and precise in the city of Lanao.

In this instance, the speaker all but swears on the truth of his assertion about the descent or bloodline of the bride's family or clan. Heused simile "like gold" and likens it to gold of the purest kind - bolawan $i$ irang a limpiyo - unalloyed or free of any impurity. Kapamakala (increasing) of relatives is bound up with kaseselai (honoring). The ultimate message here is, by elevating one's kin, a person also elevates himself and his bangsa (lineage) in general.

\section{Kambatabata (Tightening Relationship)}

The reason for the union of the two as shown in the speeches is to maintain the bangsa (lineage) through alliances and maintenance of ties based on mutuality or reciprocity. These are emphasized by using figures of speech delivered by the speakers- kapangilaylay/paegilayan sa kamapiyaan (looking for goodness), sa kailot andamanaya sa andang a kapapagariya iran (to tighten the old friendship), kaphepaka bager angkuto a kapekahgakut o mbaya-bataa (strengthening the tightened relationship), na so pakawatan na pakarani (what is distant becomes near) and pkabekes a kanggiginaway (to tighten the friendship).

The speakers emphasized one important theme in their speeches regarding marriage. They believe that through marriage, they will be able to tighten their relationship. Generally, Meranaws do not subscribe to the Western romantic concept of marriage -marrying in the name of love. Other purposes or motives, sometimes more important, are served by marriage among the 
Meranaws: for political reasons and maintaining cultural values or practices. Despite the relentless onslaught of modern ideas or influences, Meranaws still cleave to certain cultural practices like arranged marriage for the mutual benefit of families.

\section{Conclusion}

Language is intrinsically related to culture. It performs the social function of communication of the group values, beliefs, and customs and fosters group identity feelings (Bakhtin 1981). You cannot understand a culture without understanding their language. Edward Sapir, in his studies with Benjamin Lee Whorf, recognized the close relationship between language and culture, concluding that it was not possible to understand or appreciate one without knowledge of the other" (taken from Wardhaugh, 2002, p. 220).

The texts from the collected speeches lend themselves well to Critical Discourse Analysis (CDA) in analyzing the linguistic features of the Meranaw speeches during wedding. They do reveal a wealth of information about Meranaw culture and society, particularly ideological elements grouped sociocultural, religious and political values.

What is discernible in the texts as discourse is the intent to perpetuate the status quo, specifically the hegemony or dominance and influence of the ruling class (pegawidan) promote the interests of said group. In fact, this hegemony or authority is described as practically "etched in stone", that is based on the taritib (and igma. The atoren better known as taritib which forefathers laid down as a code, a set of so-called first principles and system of beliefs and values that the venerated loks agreed on (igma) is monolithic and sacrosanct; it must remain inviolable.

Language, which should be used as an instrument of needed or meaningful change, instead serves the traditional system. The stratification of society or division of the Meranaws into the pegawidan and the pegawid based on bangsa or descent, for example, is still very much at work in Meranaw society despite the rise of a new class of educated and even affluent individuals or families. Kapsalsila is still practiced to trace the lineage of people like prospective brides and grooms. These practices are demonstrated in Meranaw orature or public speaking which, for the most part, is devoted to cataloguing or dress parade and lavish introductions, complete with titles or ranks, of important figures in Meranaw society, the enumeration of connections or ties, and tracing of the pedigree of principals or major characters in an event. The dominance of the elite is cast in bolder relief. It is hardly consoling that the cataloguing of important people has broadened to include religious leaders, local government officials, and professionals.

Meranaw rhetoric or public speaking is of, by, and for the status quo. The Meranaw rhetor, usually male, serves as a gatekeeper as far as language use is concerned. He is an arbiter of taste, modelling elegance, finesse, and kambilang a tao or sensitivity to his audience's sensibility, beliefs and values, and taste. At the same time, and more importantly, perhaps, he promotes and helps perpetuate discursive practices and traditional beliefs and practices held dear and zealously fostered by the establishment. Perhaps, at this point in time, one can only hope that the younger generation of Meranaws from which shall spring new rhetors will be more attuned to functions of discourse or language other than communication and reflecting reality, like the practice of critique such as exemplified by Foucault and the exponents of Critical Theory and Critical Discourse Analysis headed by Fairclough and Van Dijk.

This study is beneficial not only to the Meranaws to understand their culture but also for the outsiders to see the Meranaw's practices objectively for them to understand the beauty and unique features of the Meranaw language and how this features manifest values and belief of the Meranaws about marriage in public speaking. Furthermore, the Meranaws must preserve this art of speaking for future generation. Otherwise, it will be forgotten. As what Baker said, " the loss of language means the loss of culture and identity"(Baker, 2001).

The art of Meranaw katharo sa lalag (delivering a speech) is very unique and rich with linguistic features. The author recommends its preservation as a distinctly Meranaw verbal art so it will continue to produce and develop verbal art forms and serve as a vital function of language as transmitter of identity and unique ideology including beliefs and values of the Meranaw.

Lastly, the researcher recognizes that there is scarcity and limitation in this study. There are many ceremonial speeches such as engagement and enthronement which are equally important ceremonies of the Meranaws but the researcher focused only on wedding. Thus, inclusion of other speeches delivered in other ceremonies will make the study more accurate. Future researchers may include them. The researcher recommends studying the said speeches to compare whether there is similarity or differences of linguistic features presented. Other linguistic features may be identified which will reveal other values. 


\section{References}

[1] Alonto, A., Andam, A., Zorc, D. (2009). Dialog and drills. Dunwood Press. Extract

[2] Bhatia, V. (2004) worlds of written discourse: A genre-based view. Vijay K. .New York: Continuum

[3] Brognoli, A. (1990). Language and ideology: A case study of 'sesame street'. Universidade Federal de Santa Catarina. Centro de Comunicaçãoe Expressão.

[4] Baker, P., Ellece, S. (2011). Key terms in discourse analysis. Continnuum International Publishing Group.

[5] Barthes, R. . (1967). Elements of semiology. New York: Hill and Wang

[6] Bhatia, V. K. (1993). Analysing genre: Language use in professional settings. : Longman

[7] Brown, P. \& Levinson, S.C. 1987 [1978]. Politeness: Some universals in language usage.: Cambridge University Press.

[8] Dellner, A. (2014).Cultural dimensions: The five-dimensions-model according to Geert Hofstededge. Grin Verlag

[9] De beaugrande, R. (1984). Text production: Toward a science of composition, advances in discourse processes ser., Vol. 11. Greenwood Publishing Group.

[10] de Saussure, F. (2011). Course in general linguistics. University Press

[11] Dijk, T. (June, 2006). Journal of Political Ideologies

[12] Disoma ER. (1990). The maranao: A study of their practices and beliefs. Julbert Press.

[13] Gee, J. (2014). An introduction to discourse analysis: Theory and method. Routledge

[14] Gudykunst, W. (2003). Cross-Cultural and Intercultural Communication. Saga Publication, Inc.

[15] Fairclough, N. (1992.) Language and power. Longman

[16] Fairclough, N. (1995). Critical discourse analysis. Longman

[17] Fairclough, N. (1992). Critical discourse analysis, the critical study of language. Harlow: Longman

[18] Gudykunst, W. (2003). Cross-Cultural and Intercultrural Communication. Saga Publication, Inc.

[19] Goffman, Erving. 1967 Interactional rituals: Essays on face-to-face behavior. New York: Doubleday.

[20] Gunther, K. (1993). Language as Ideology. Second Edition. London EC4P 4EE: Routledge.

[21] Halliday, M. (1978). Language as social semiotics; the social interpretation of Language and Meaning.. University Park Press.

[22] Halliday M.A.K., Matthiessen, C., Halliday M. , Matthiessen, M. (2014) An introduction to functional grammar. Routledge

[23] Hodge, R. and Gunther, K. (1988) Social semiotics. Cambridge

[24] Holmes, J. (1986). Compliments and compliment responses in New Zealand English. Anthropological linguistics, 485-508.

[25] Jaworski, A. and Coupland, N. (1999). The discourse reader. Routledge

[26] Kampf, Z.(2009). Public (non-) apologies: The discourse of minimizing responsibility. Journal of Pragmatics

[27] Madale, A. (1976) The Remarkable Meranaws. Omar Publications. Quezon City, Philippines.

[28] Martin, J. R., \&White, P. R. R. (2005). The Language of evaluation: appraisal in english. London, UK: Palgrave Macmillan.

[29] Michener, A., Delamater, J., Daniel J.(2004) Social Psychology. Wadsworth, Belmonth, CA.

[30] Mcllwaine, J., Whiffrin, J., (2001). Collecting and safeguarding the oral traditions: an international conference. IFLA Publications 25. The Hague, The Netherlands: International Federation of Library Associations.

[31] Mufwene, S. (2008). Language evolution: contact, competition, and change. Continuum International Publishing Group.

[32] Newton, T. (1999). Stress discourse and individualisation.London: Sage.

[33] Paltridge, B. (2006). Discourse analysis: an introduction. Bloomsbury Publishing

[34] Potter, J. (1997). Representing reality: discourse, rhetoric and social construction. SAGE Publication

[35] Rasul-Rogong, N. (2015). "Traditional and modern democratic government: envisioned contemporary local governance in lanao del sur." Unpublished Doctoral Dissertation, Mindanao State University, Marawi City.

[36] Richard, J. Platt, J. and Weber. H. (1985): Longman dictionary of applied linguistics, London: Longman Group Ltd.

[37] Riwarung, Labi Hadji Sarip. Language Conservation and Documentation. 5. (2011), pp. 31-59 Mindanao State University, Islamic City of Marawi

[38] Rogers, R. (2004). An Introduction to Critical discourse Analysis. In R. Rogers (Ed.), An Introduction to Critical Discourse Analysis in education.

[39] Shafaat, H (2003).Critical discourse analysis: demystifying the fuzziness. The International Journal Of Humanities \& Social Studies

[40] Saber, M., Madale, A. (1975). The Magical and curative practices. In Mamitua Saber and Abdullah Madale, eds., The Maranao. Manila, Philippines: Solidaridad Publishing House.

[41] Schiffrin, D. (1987) Discourse markers. Cambridge University

[42] Silverstein, M. (2008). Ideology and interest in the defense of languages. Bloomsbury Publishing

[43] Swales, J. M. (1990): Genre analysis - english in academic and research settings.

[44] Cambridge University Press

[45] Tawagon, N. (1987). The pengampong: a historical study of the multiple sultanate of Lanao. Mindanao. Department of History, Mindanao State University.

[46] Van Dijk, T (1996). Discourse, Racism and ideology. RCEI Ediciones.

[47] Van Dijk, T (1998). Ideology: A multidisciplinary approach. SAGE Publication

[48] Van Dijk, (2004). Ideology and discourse: a multidisciplinary introduction. , Roma Publisher.

[49] Van Dijk, (2011). Discourse studies: a multidisciplinary introduction. SAGE Publication

[50] Weaver, R.M. (1967). A rhetoric and handbook. New York, NY: Holy, Rinehart and Winston.

[51] Wodak, R. (2001) Critical discourse analysis. Sage Publication

[52] Yuan, Y. (2002). Compliments and compliment responses in Kunming Chinese.Pragmatics, 12(2), 183-226 